\title{
O regresso de Júlia Mann a Paraty de Teolinda Gersão: refrações miméticas e jogos intertextuais \\ Recensão
}

As teorias miméticas da literatura que se revêm nos pressupostos epistémicos da Poética de Aristóteles colocam a sua ênfase nas relações entre o texto e a realidade que lhe é exterior ou, em termos que evocam a teoria idealista do conhecimento, que a representam literariamente. $\mathrm{O}$ texto como dispositivo verbal reprodutor da realidade empírica ou imaginária, ou como imitação discursivamente mediada, serve também de fundamento à monumental dissertação Mimesis, de Erich Auerbach, sobre o devir da literatura ocidental - da Odisseia de Homero e do episódio do sacrifício de Issac no Génesis bíblico ao romance de Virginia Woolf To the Lighthouse. Convocámos os magistérios de Aristóteles e Auerbach porque as suas lições sobre o conhecimento do fenómeno literário nos parecem ser instrumentais para orientar e justificar, à luz da sua elevada probabilidade de pertença à linhagem da ficção mimética, a leitura crítica do tríptico novelístico O regresso de Júlia Mann a Paraty, de Teolinda Gersão. Tal como três painéis pintados segundo um programa narrativo que adquire o seu pleno sentido se a sua discreta tripartição for observada na unidade do seu conjunto, assim os três textos reunidos nesta recente obra de Teolinda Gersão sob o nome artístico-literário Mann ganham, na sua relativa e singular autonomia, em serem lidos na perspetiva da sua totalidade dialógica. Se a personagem estruturante do tríptico é, pela sua relevância estética literária, o escritor alemão e prémio nobel Thomas Mann, que ocupa o lugar central e configurador da segunda das três novelas, as outros personagens que o ladeiam nos outros dois painéis, respetivamente na primeira e terceira novelas, são o fundador da psicanálise, Sigmund Freud, e a sua exótica, afetiva, descomprometida e corajosa mãe, Júlia Mann. Estamos, portanto, diante de três exercícios ficcionais em torno de três personalidades reais, duas das quais, Freud e Thomas Mann, ocupam lugares cimeiros na história das ideias e da literatura, e uma terceira, a mãe real do escritor, resgatada por Teolinda Gersão do limbo da menos conhecida, mas fascinante e complexa genealogia associada ao nome totémico dos Mann.

A ordenação da representação ficcionada dessas três personalidades não é, porém, cronologicamente linear nem suscetível de ser lida numa sequência organicamente causal, mas 
disposta de modo a desafiar a coerência lógica-ontológica da triádica composição textual. Teolinda Gersão não nos dá primeiro a ver o retrato de Júlia, progenitora de Thomas Mann, seguido dos retratos deste e do de Freud, escrutinador de aspetos determinantes e idiossincráticos do carácter do escritor alemão. A autora opta, antes, por dispor temporalmente os retratos a contrario: o do psicanalista, que, pela sua função de hermeneuta-terapeuta exterior à sucessão genealógica, devia figurar no último painel como o derradeiro texto, é o que abre a sequência - "Freud pensando em Thomas Mann em 1938"; segue-se o do psicanalisado, que ocupa o lugar central do tríptico e é desenhado precedendo aquele em oito anos - " Thomas Mann pensando em Freud em Dezembro de 1930"; e, por fim, o da figura matricial de Júlia Mann que, por inferência do conteúdo do texto, é reconstituído retrogressivamente a partir do ano da sua morte em 1923. Por ordem cronológica decrescente se apresentam assim três retratos correspondentes às datas de 1938, 1930, 1923, que, na variação das suas representações - os dois primeiros narrados na primeira pessoa, o último na terceira -, incorporam também sinais especulares de autorrepresentações. Três retratos que são também três auto retratos, porquanto cada um dos retratados fala ou está associado ao(s) outro(s) que retrata ou que são retratados: Freud ao pensar em Thomas Mann é também a si que se refere, e o mesmo sucede com o escritor que, ao pensar no psicanalista também se pensa a si; já o retrato omniscientemente narrado de Júlia incorpora a memória de si no distendido foco narrativo que abarca as suas ascendentes e descendentes relações familiares, nelas incluídas as que estabeleceu com o seu filho Thomas. A sequência cronologicamente decrescente da ordenação das três novelas parece assim obedecer a uma estratégia narrativa que, preservando a coerência da sua singularidade diegética, visa potenciar os elos intertextuais que entre si se podem discernir, ao mesmo tempo que, por efeito en abyme, formalmente reprodutor do fio narrativo da última novela que dá título à obra, institui o movimento temporalmente regressivo de uma circunstância de vida ulterior para um estádio de vida anterior - e que na novela mencionada corresponde ao movimento de regresso à infância de Júlia Mann a Paraty por via da reconstituição ficcional da sua vazante corrente de consciência no momento iminente do seu falecimento em Wessling, na Baviera alemã. Mas é também uma estratégia narrativa que pode suscitar uma outra leitura en abyme, a de se considerar que o pensamento de Freud sobre Thomas Mann se processa no âmbito dos protocolos da psicanálise mediante os quais se procura identificar e trazer à consciência do paciente as causas remotas dos seus recalcamentos, se busca analisar a partir de um dado presente as circunstâncias traumáticas do passado, se intenta elucidar, num momento ulterior e num ambiente clinicamente estabelecido, os sintomas das perturbações psíquicas inconscientemente associados a situações infaustas ocorridas em momentos necessariamente anteriores. Abissal é portanto a organização global desta obra de Teolinda Gersão e, por isso, especular, plena de reenvios e interseções de significados concebidos com a coerência da precisão de um jogo de espelhos, porém com inesperados pontos de fuga, e em que as principais personagens das duas primeiras novelas se auto revelam no processo de pensarem o outro que se propõem lucidamente revelar - Freud: "[A]través de si, também estive a refletir sobre mim próprio"(36); Thomas Man: "Esta conversa é uma espécie de confissão" (75). Nesses implacáveis monólogos 
escrutinando as idiossincrasias alheias, ambos os protagonistas constatam a natureza interdependente da sua relação cordatamente distante - Freud: "Lembro-me por exemplo de lhe ter enviado 0 mal-estar na civilização, em agradecimento pelo seu ensaio A posição de Freud na moderna história das ideias" (10); T. Mann: "Falamos a mesma língua, Dr. Freud [a] do espírito, que nos conduz a revelações e iluminações [...] a divina língua das epifanias" (52). Apesar de marcada por afinidades intelectuais e pelo comum reconhecimento da dedicação à respetiva obra e vocação autorais - Freud: "[P]artilhei com Thomas a entrega incondicional a uma obra, que seria para ambos o centro das nossas vidas" (16); T. Mann: "[0] senhor é a obra que ao longo da vida foi escrevendo."(50) - , a relação evocada por cada uma das duas singulares vozes surge representada pelo estigma de não se consumar na experiência vital, e não meramente intelectual, da amizade - fracasso afetivo que é compensado, todavia, por um sentimento reversível de compaixão, quer pelos efeitos trágicos da personalidade do escritor - Freud: "Enquanto médico, creio que nunca senti maior compaixão por ninguém" (24) -, quer pelas agruras públicas sofridas pelo diagnóstico pessimista do psicanalista sobre "uma sociedade cruel, baseada em rivalidade, incesto e parricídio [...] onde a civilização causa mal-estar e a felicidade arrebatadora da fusão é ilusória" (51) - T. Mann: "Sim, eu compreendo-o, e sinto compaixão por si" (idem). O testemunho da mútua cordialidade, da comum devoção axiológica à sua respetiva vocação profissional e a recíproca compaixão, não elidem porém as irredutíveis diferenças de carácter das duas personagens: o que na especular observação das imagens do outro indicia uma aparente cumplicidade encobre o que de essencialmente antagónico as separa - Freud: "Ao contrário dele, nunca estive interiormente dividido" (17); T. Mann: "Os nossos caminhos cruzam-se, o senhor sabe-o também como eu. Embora, por outro lado, sejamos muito diferentes" (50). Do ponto de vista da modulação enunciativa, dir-se-ia então que a figura superficial do quiasmo, Freud pensando em Thomas Mann / Thomas Mann pensando em Freud, envolve e cobre a figura em profundidade da antítese, Freud e Thomas Mann pensando-se por oposição. É aliás esta figura da antítese, enquanto manifestação retórica do drama ontológico representado por fragmentos ficcionados da vida das três personagens, Freud, Thomas e Júlia Mann, que predomina e se reproduz no encadeamento narrativo das três novelas. É a dialética da contradição que, de facto, sobrevém na exposição enunciativa das figuras retratadas, não necessariamente porque se apresentem como figuras irredutíveis entre si, mas porque na narração auto referencial de Freud e T. Mann e na omnisciente de Júlia Mann, se projetam as tais linhas de fuga que alargam o horizonte e a profundidade do campo narrativo, nele incluindo outras figuras que com elas interagem e contracenam. É assim que, na primeira novela, a personagem convocada pelo narrador Freud para comunicar o problemático relacionamento com uma personalidade artística em que se revê e com quem se identifica como se fosse um duplo desejado de si, não é, surpreendentemente, T. Mann, mas o escritor médico Schnitzler, que a um tempo suscita a sua admiração e a sua inveja: "Imaginei-me vezes sem conta no lugar dele [...], sonhei ser um grande escritor como ele: bafejado pela inspiração, seguir livremente o instinto e descobrir numa iluminação o que procurava, sem o esforço imenso do conhecimento científico e a demorada reunião das provas necessárias" (17-18). O médico e escritor Schnitzler insinua-se no 
pensamento de Freud, porque este, ao se identificar parcialmente com aquele, não só o converte num simulacro ideal de si, no artista que não era e desejaria ser, como também o toma como o seu eletivo destinatário confessor, aquele que pela sua condição de "corajoso pesquisador da psicologia profunda" (20), mais capacitado estaria para compreender a sua frustração de um racionalista privado da intuição artística que ambicionava possuir. A honesta confissão redigida em carta por Freud ao médico e escritor Schnitzler, em parte movida negativamente pela pulsão da inveja assassina de liquidar o (semi) duplo de si, desempenha, portanto, no contexto da sua reflexão sobre T. Mann, o efeito sublimador de salvaguardar a sua cordialidade, se não mesmo o seu sentimento de compaixão pelo escritor, dele desviando para outrem a inveja auto reconhecidamente causada pelo seu défice de criatividade estética. Poder-se -ia então considerar que a personagem do médico Schnitzler (enquanto alter ego do médico Freud) e, por efeito de uma transferência sublimadora deste (o escritor Schnitzler, enquanto alter ego de T. Mann) opera, no contexto narrativa da primeira novela como um personagem fantasmática e especular; mas Schnitzler também opera, enquanto protagonista das linhas de fuga dos retratos e autorretratos singulares propostos nas três novelas, como uma personagem instrumental para a consumação da estratégia de uma narração global en abyme. Decorrente de um sentido de emulação, que é outra forma de declinar a figura da antítese, verifica-se, portanto, um paralelismo de situações e um padrão de comportamentos narrativamente representados que transmigram diegeticamente entre as três novelas. Assim, por exemplo, o antagonismo paradoxal de Freud em relação a Schnitzler - "além de o admirar, invejei-o [...], através da intuição o senhor sabe tudo aquilo que eu só através de um trabalho lento e penoso fui levado a descobrir noutras pessoas (18-20) - reverbera na consciência competitiva e no sentimento de inveja que T. Mann experiencia para com o seu irmão também escritor - "Admiro e desprezo Heinrich de igual modo. Invejo a sua criatividade torrencial, a rapidez com que escreve e publica [...] porque eu sou fraco, lento, cheio de incertezas" (64) - antagonismo que por sua vez surge angustiosamente atestado pela mãe de ambos os escritores - Júlia Mann: "[...] era em Heinrich que agora se concentrava. Como ele sofreria, se Thomas tivesse recebido o Nobel. [...] Toda a vida lutara em vão para que se entendessem [...] Mas cada livro que escreviam era contra o outro, na esperança de o deixar de rastos" (109).

O mútuo respeito intelectual entre Freud e T. Mann não tolhe, porém, o mútuo sentido crítico de ambos sobre a avaliação da vida e das peculiaridades de feitio que tecem um sobre o outro. Os seus respetivos monólogos assinalam esse sentido crítico, progredindo no encadeamento dos seus juízos como se pressupusessem a presença do outro, como se os processassem numa situação de diálogo - Freud: "Este é o seu retrato, Thomas. Olhe para si" (33); T. Mann: "Imagino-me de facto muitas vezes a falar consigo, como agora" (53). Neste diálogo virtual cindido em dois efetivos monólogos estabelecem-se nexos argumentativos e de correspondência de sentido recorrentes que fazem com que estas duas primeiras novelas do tríptico revelem índices de inter e intratextualidade mais nítidos e frequentes que os que se podem discernir na terceira novela, se bem que esta não deixe, na sua maior autonomia diegética e temática relativamente àquelas, de se articular estruturalmente com ambas - sobretudo nos 
tópicos da competição malsã entre Heinrich Mann e Thomas Man e das problemáticas relações deste com a sua família enquanto pai, marido e filho.

A estratégia de composição intratextual das três novelas e, em particular a que desenvolve o tópico - central na psicanálise - das tensões inter parentais, é, porém, habilmente orquestrada num nível metaliterário e suportado no conhecimento da germanista Teolinda Gersão da obra de Heinrich e Thomas Mann. As alusões, devidamente inseridas no fluxo discursivo da narração, a obras literárias de ambos os escritores não só atuam como subtextos que ilustram a referida dimensão representacional da obra, mimetizando situações singulares e arquetípicas do mundo humano, como também servem de fundamento e suporte aos juízos das personagens que os convocam. Assim, por exemplo, para Freud, o romance José e os seus irmãos de T. Mann não é mais, sublinhando-o enfaticamente ao destinatário do seu pensamento, do que "a história da sua relação com Heinrich, o seu irmão mais velho" (27), enquanto a narrativa Desordem e sofrimento precoce, refletindo a rivalidade transferida do irmão Heinrich para o filho Klaus "é um livro transparente sobre conturbadas relações familiares, que são as suas" (29), algo que o escritor confirma quando, à maneira de uma rima emparelhada, confessa a Freud ser aquela obra "o retrato da nossa família. [...] As personagens que representam Erika e Klaus [...] são inseparáveis, vestem roupas um do outro, fazendo-se passar por gémeos, são rebeldes e provocadores, vivem fora das normas e retiram prazer do escândalo que provocam" (70). Já o conto $O$ Sangue dos Walsungs sobre o tema do incesto assumido pelas personagens Sigmund e Sieglinde, que replicam onomasticamente a identidade dos protagonistas da ópera, inspirada na mitologia alemã, de Wagner A Valquíria é um assumidamente cínico exercício de escrita de T. Mann para revelar à família judia da sua esposa, Katia, o conhecimento que tinha da relação incestuosa que ela mantinha com o seu irmão, Klaus: "Como Sieglinde e Sigmund, partilhavam no nome a mesma inicial: K envolvia os dois" (59). Também as suas novelas Mário e o mágico e As confissões do impostor Felix Krull seriam construções ficcionais com inspiração num fundo autoreferencial espelhando difusamente as marcas manipuladoras, impostoras e amorais do seu próprio caráter. Por sua vez, Júlia Mann não ignorava que ambos os seus filhos escritores se inspiraram na sua materna ascendência luso-brasileira e mestiça para esconjurarem em algumas das suas obras o estigma rácico conotado com a imagem da mulher estrangeira, uma personagem frequente nos livros de T. Mann. Assim sucedera "desde logo em Tonio Kröger, e [...] em múltiplas variações de figuras femininas, em muitos dos seus contos e romances" (114) mas também ocorrera nas narrativas ficcionais de Heinrich Mann, Numa Família e Entre Raças. Ao exotismo destas personagens romanescas femininas, que Júlia interpreta como refrações literárias da sua imagem de mulher estrangeira sujeita ao olhar de uma sociedade alemã culturalmente conservadora e refratária a miscigenações étnicas, associa-se também a da imagem da mulher sensual, perigosamente lúbrica e sedutora : "A muitos milhares de quilómetros de distância, a América do Sul, e nela o Brasil, representavam, no seu imaginário [dos filhos] uma fonte inesgotável de perigos de ordem física, mental e moral" (115).

O tópico da raça e da sua sujeição histórica à discriminação e perseguição movida por estereótipos ideológicos com origem em preconceitos e desconfianças culturais, sendo mais 
evidente no motivo da última novela, pelas irradiantes correlações de sentido que nela se estabelecem associadas à reconstituição da vida filial, matrimonial e maternal de Júlia Mann, surge também narrativamente declinado nas duas outras narrativas: quer na alusão que Freud faz ao seu estatuto de um alemão-judeu exilado em Inglaterra em consequência da perseguição anti semita nazi - "Vim morrer nesta ilha inglesa. [...] Durante quase toda a vida, apesar da minha ascendência judaica, sentir-me culturalmente alemão era um dado irrefutável. [...] A Alemanha regrediu milénios, e mergulhou numa barbárie a que poderíamos chamar pré-história" (8) -, quer na confissão de Thomas Mann sobre as conveniências pessoais, financeiras e sociais do seu matrimónio com Katia, filha de uma família judia abastada de Munique, cultural e intelectualmente notável: "Os Pringsteins eram judeus, por conseguinte etnicamente inferiores a mim. [....] Dinheiro e luxo eram uma pequena contrapartida pela minha disponibilidade para aceirar uma mulher judia. [...] Deveriam ainda estar-me gratos pelo meu sangue germânico que a protegeria de ameaças anti-semitas" $(59,60)$.

As refrações miméticas e os jogos intertextuais que compõem os motivos deste tríptico narrativo - da raça, da família, da literatura - nos seus complexos processos de iteração discursiva conferem uma tonalidade sombria feita de equívocos e dissimulações ao seu efeito de conjunto. Mas, ao mesmo tempo e, paradoxalmente, conferem uma transparência global feita de revelações e iluminações dos traços de caráter, associados a episódios fundamentais de vida e a relações humanas de amizade e familiares das personas dos três protagonistas, Freud, Thomas e Júlia Mann.

Um outro exemplo dessa construção anafórica interdiegética, sombria no tom mas translúcida na revelação da origem desse tom, é o motivo do amor. A sua ausência é enunciada a propósito das relações de Júlia e Thomas, o homónimo pai do escritor, e deste em relação aos seus filhos e filhas, como também é confessado por Thomas escritor em relação à sua mulher Katia e à maioria da sua progénie. Freud identifica assertivamente a causa desse défice de afetividade ao pensar no destinatário objeto do seu monólogo: "Thomas não amou verdadeiramente ninguém, a não ser a si próprio. [...] Relacionava-se com seres humanos como rivais a abater, ou objetos ao seu serviço. Nunca amou mulher nenhuma, muito menos Katia. As paixões por outros homens foram muito mais imaginadas que reais" (15). O diagnóstico do psicanalista é contundente: "Acima de tudo, o senhor é hesitante e ambíguo. Incapaz de amar, olha para o mundo com descrença, disfarçando o seu desespero e pessimismo com um a ironia cativante" (33). Por sua vez T. Mann, ao reconstituir uma hipotética sessão de psicanálise com Freud e imaginando os benefícios afetivos e libertadores que terapeuticamente obteria desse encontro, conclui pensando: "Talvez o senhor não saiba, mas o amor é isso. Não o senhor não sabe. É incapaz de falar sobre ele, porque o desconhece" (54). À quase crueldade que Freud coloca no diagnóstico que faz da psique e do ethos do escritor, relevando a sua homossexualidade reprimida e literariamente transfigurada na novela Morte em Veneza, corresponde simetricamente o desdém de T. Mann pela pretensão racionalista de Freud de querer regular a sua coragem artística de explorador das possibilidades amorais da existência humana, de intentar subordinar à mediania da normalidade assética e desvitalizada a sua liberdade criativa de escritor. À voluntária, mas 
frustrada, expetativa de Freud se dispor a analisar e tratar os demónios de T. Mann, contrapõe T. Mann a proposta de inverter os papéis da relação terapêutica psicanalítica. À "pulsão fáustica" que o psicanalista reconhece no escritor, e que este assumidamente confirma, sucede a acusação feita pelo escritor à prepotência autoritária exercida pelo psicanalista junto dos seus discípulos. E, no entanto, apesar do antagónico e veemente tom judicativo que aflora em ambos os monólogos, cada um dos seus protagonistas não deixa, por fim, de constatar convergentes traços de caráter - Freud: "Apesar de todas as nossa diferenças, que são muitas, talvez eu esteja mais próximo de si do que imaginava" (36); T. Mann: "Interrogo-me se não poderíamos [...] ter agora um encontro, em perfeito pé de igualdade. Um momento de paz, de dádiva recíproca [...], apenas fatigados companheiros de viagem que seguem juntos, amparando-se um ao outro" (52). Cada qual acaba não só por declarar o respeito e admiração pela obra intelectual do outro, como revela um anseio cruzado, suspenso de pudor, de se reconhecer, também, senão na amizade, na cumplicidade do seu comum destino de seres pensantes, indagadores dos mitos e da dimensão obscura da existência humana - T. Mann: "Apesar da visão sempre irónica, o meu mundo de criação artística é uma procura de absoluto, para além das palavras, uma espécie de perda de identidade, onde todos os antagonismos se equilibram, e o bem e o mal se confundem (76); Freud: "Também eu percorro o mito e o passado, desço a abismos e infernos, ao mundo subterrâneo da humanidade e da infância, na vida individual e coletiva" (38).

É o percurso às origens da dimensão trágica da vida de T. Mann - que este assume como sendo remota e transpessoal, "A minha vida é uma tragédia à moda antiga, em que uma espécie de maldição se propaga através de gerações" (53), e que Freud prevê como inevitável: "No fim a sua obra vai salvar-se mas o senhor não." (31) -; é a reconstituição das causas e condições familiares desse destino fatal e transmigrante, envolvendo a recordação da infeliz vida da mãe do escritor, exilada do seu paraíso nativo de Paraty, no Brasil, e desde jovem adolescente aculturada na cidade alemã de Lübeck; é essa representação das circunstâncias sociais envolvendo o sofrido processo de individuação de Júlia Mann, da sua difícil condição de filha, esposa, mãe e amante; é, finalmente, a representação simbólica do processo da sua morte como uma viagem fluvial e marítima de regresso à sua terra nativa, que configura o tema da última novela. Toda a narração dos episódios fundamentais da vida de Júlia Mann, enquadrados no início e no fim pela evocação da experiência da sua morte, subsumem-se à seguinte afirmação, com valor de uma anagnórise trágica, do narrador: "Ela conhecia o sentimento de exclusão, uma dor constante, pervertendo tudo. Mas nenhuma dor fora tão grande como a que sofrera pelos seus filhos, ou fizera sofrer os seus filhos" (136).

O predomínio da memória, do recurso à evocação ulteriormente narrada de cenas do passado, não só perfaz a diagnose do pensamento de Freud sobre T. Mann, como ampara a vontade sublimadora da verdade recalcada de si em passagens do monólogo de T. Mann sobre Freud, e serve de sustentação ao relato omnisciente da vida trágica de Júlia Mann. A anamnese é, portanto, o dispositivo retórico geral ou pano de fundo que congrega este tríptico novelesco. É à sua luz que se reconstitui a lembrança de algumas ténues clareiras de felicidade filial e maternal - T. Mann: "Recordo sobretudo as férias de Verão, em Travemünde, onde os dias passavam 
como se a realidade à beira-mar acontecesse noutra dimensão" (49). Anamnese que, além de operar como dispositivo ficcional com valor de catarse, reproduz o jogo intertextual que define a arquitetura da diegese - "Mas por enquanto era ainda o Trave, à beira do qual [Júlia] gostava de passear, e em cuja foz costumava ir à praia, em Travemünde - dias felizes para as crianças, que corriam e brincavam na areia" (82). Anamnese que, por associação, instaura referências e imagens em discretos mas interrelacionáveis níveis de refração mimética, tal como sucede, por exemplo, com a evocação de Travemünde, lugar de ocorrências felizes e promissores, transfiguráveis em dramáticos motivos ficcionais dos irmãos Mann - "Naquela mesma praia a tia Elizabeth, quando era jovem, apaixonara-se por um estudante com ideias socias novas. [...] mas o rapaz era de condição inferior, e casar com ele estava absolutamente fora de questão, A história da tia Elizabeth era a de Tonia Buddenbrook. Toda a história da família estava nos livros em que Thomas a descrevia, e por vezes também nas histórias que Heinrich imaginava" (82). Anamnese, por fim, que, ativando a composição do motivo arquetípico da nostalgia do paraíso perdido, flui simbolicamente como a água do rio da morte de Júlia Mann, do rio Trave, no Báltico, até ao Paraty, no Atlântico sul, ao encontro do amor da ama e do lugar genesíaco da inocência possível e ilusoriamente trágica: "Mas ainda não queria abrir os olhos. [...] Queria ficar ali ao sol, de olhos fechados, sentido a areia colar-se ao corpo. A mãe tinha morrido. Essa ferida doía muito. Mas Ana estava lá, [...] e viria cantar-lhe cantigas ao ouvido e dizer-lhe que, quando crescesse e fosse mulher, iria ser feliz, imensamente feliz" (140). Anamnese que, fechado este tríptico, se pode condensar na palavra "saudade", que talvez Júlia tenha ouvido na língua portuguesa da sua infância. Palavra que o poeta português Pascoaes, seu contemporâneo, tomou para designar a "eterna vida", e que, en abyme, opera como o ténue fio de luz que atravessa a sombria e densa representação da tormentosa e tumultuosa vida dos Mann, ficcional e refratariamente reconstituída por Teolinda Gersão. 